\title{
The Good Salted egg using AHP
}

\author{
B. Ayshwarya, Phong Thanh Nguyen, Firmansyah Y. Alfian, Wahidah Hashim, K. Shankar, Yanti \\ Aprilda, Sri Ipnuwati, Pavel A. Melnikov, Andino Maseleno
}

\begin{abstract}
In the globalization era like nowadays, advertising marketing activities have become a trend in the world of communication to market products to the public. In order to be able to popularize a product that is less known by public, marketing can be an effective means of introducing the product to the wider community. The subjects in this study were decision support systems using the Analitical Hierarchy Process (AHP) method and the results of AHP calculations that can provide opportunities for program manager to be able to build ideas and define existing problems by making assumptions in a hierarchy and then get the desired solution and apply intelligently a complex mathematical approach based on a qualitative approach that can be accepted by all stakeholders and program managers. In this study, it was observed to consist of two factors, namely the factors of constraint and supporting factors with the criteria and sub-criteria considered by the two factors and alternatives that would later be chosen as the best marketing strategy for increasing sales of salted eggs. Based on the results of the study, alternative A1 produced a weight of 17 by occupying priority 1, alternative $A 2$ produced a weight of 10.6 with occupying priority 2.
\end{abstract}

Index Terms: Analytical Hierarchy Process, marketing mix, salted egg micro enterprise, salted egg marketing strategy.

\section{INTRODUCTION}

\section{A. Background}

The decision to buy is on consumer and consumer will use various criteria in buying good and brand that suit their needs, taste and purchasing power [1-5]. Strict competition between brands will make consumers have a stronger position in bargaining [6-9]. The success of a product to be continuously consumed by consumers is supported by effective marketing activities [10-14]. The tendency of non-loyal consumers, namely to choose the best product with

Revised Manuscript Received on July 22, 2019.

B. Ayshwarya, Department of Computer Science, Kristu Jayanti College, Bangalore-560043, India.

Phong Thanh Nguyen, Department of Project Management, Ho Chi Minh City Open University (HCMCOU), Vietnam.

Fimansyah Y. Alfian, Darmajaya Institute of Informatics and Business, Lampung, Indonesia.

Wahidah Hashim, Institute of Informatics and Computing Energy, Universiti Tenaga Nasional, Malaysia.

K. Shankar, School of Computing, Kalasalingam Academy of Research and Education, Krishnankoil, India.

Yanti Aprilda, Department of Information Systems, STMIK Pringsewu, Lampung, Indonesia.

Sri Ipnuwati, Department of Information Systems, STMIK Pringsewu, Lampung, Indonesia.

Pavel A. Melnikov, Togliatti State University, Russia

Andino Maseleno, Institute of Informatics and Computing Energy, Universiti Tenaga Nasional, Malaysia. E-mail: andimaseleno@gmail.com the desired quality, as long as the price is in accordance with the size [15-19]. Thus, it is expected that the implementation of effective marketing can stimulate consumers to buy these products [20-24]. In reaching consumers, salted egg micro enterprisees forms a marketing area in all remote areas in Pringsewu District.

The Decision Support System in improving micro enterprise marketing is influenced by several factors as criteria. Each criterion must be able to answer one important question about how well an alternative can solve a problem to determine the marketing of micro-enterprises. Criteria related to raw materials as natural resources, bussinessmen as human resources, road access as transportation, people's purchasing power as marketing.

Until now, the salted egg micro enterpise in Pringsewu has never carried out an analysis of the form of marketing activities that have the most influence on the benefits of micro-enterprises. Marketing analysis has an influence on product profit, it needs to be done, marketing is one of the important element in the marketing mix that has an important role in achieving a qualified micro-enterprise vision that is communicating a product so that consumers continue to remember their existence in order to achieve greater profit.

One method that can be used to analyze marketing strategies is AHP (Analytical Hierarchy Process). AHP is a quantitative technique developed for cases that have various levels (hierarchy) of analysis. This method is a practical way to handle various functionalities in a complex network. The AHP method uses pairwise comparison, calculate weighting factors, and analyze them to produce relative priorities among existing alternatives. AHP is a simple and flexible method that accommodates creativity for solving a problem

\section{B. Problem Formulation}

Based on the above background it can be formulated the problem to be solved was how to design a decision support system using AHP method (Process Hierarchy Analysis) to increase the marketing of salted egg micro enterprise based on predetermined weight and criteria. By using a program to help resolve problems so much easier and more efficient.

\section{The Scope of Problem}

In this research it is needed the limitation to make it appropriate with the planning, so it can achieve the goals. As for the scope of the problem was :

a. Sampling was done for this research obtained from businessmen information in 
sub-district level in Pringsewu District.

b. Data collection method was obtained by questionnaire.

\section{Research Objective}

The objective of this research was to develop a decision support model using AHP (Analytical Hierarchy Process) to determine alternative/area to be marketing location based on determined criteria and weight.

\section{E. Research Benefit}

a. To create decision support system to market salted egg micro enterprise.

b. As training facility and knowledge development for author in in applying theory as research base.

\section{THEORETICAL BASE}

\section{A. Micro Enterprise}

Definition of micro enterprise is an enterprise with 5 - 19 workers to process raw material or semi-finished product become finished product which has value added to get benefit.

\section{B. Decision Support System}

The concept of a Decision Support System (DSS) system was first introduced in the early 1970s by Michael S. Scott Morton with the term Management of Decision System. The system is a computer-based system aimed to help decision maker utilize certain data and models to solve various unstructured problems [25-29]. Decision support system is as a computer-based system consisting of components including system language components (language), components of system knowledge (knowledge) and components of problem processing system [30-34].

Some advantages in using DSS, among others:

1. Able to support solution finding from some complex problems.

2. Able to response quickly the unexpected situation in fluctuate condition.

3. Able to apply various different strategies in different configuration quickly and accurately,

4. New view and learning.

5. As facilitator in communication.

6. Save cost and human resources (SDM).

7. Save time because the decision can be made quickly

8. Enhance anlaysis productivity.

\section{Definition of Salted Egg} that are preserved in a way marinated (given excess salt to deactivate the remodel enzyme). Most salted eggs are from
Salted egg is a general term for egg-based dishes

duck eggs, although they do not rule out other eggs. Salted eggs are consumed in one month (30 days).

\section{Main Concept of Analytical Hierarchy Process} (AHP)

The Analytical Hierarchy Process (AHP) is a decision support model developed by Thomas L. Saaty. This decision support model will describe multi-factor problems or complex multi criteria into a hierarchy. Hierarchy is defined as a representation of a complex problem in a multi-level structure where the first level is a goal, followed by a factor level, criteria, sub criteria, and so on down to the last level of the alternative. With hierarchy, a complex problem can be broken down into groups which are then organized into a hierarchical form so that the problem will appear more structured and systematic. Analytical Hierarchy Process (AHP) is often used as a problem solving method compared to other methods for the following reasons:

1. Hierarchy Structure as consequence from selected criterion until deepest sub criterion

2. Consider the validity up to the tolerance limit of inconsistencies in various criteria and alternatives selected by decision makers.

3. Consider the durability of the output of the decision-making sensitivity analysis.

\section{RESEARCH METHOD}

\section{A. Data Collection}

As for data collection methods used in this research were :

1. Literature Research Method. It is a technique of collecting data by studying references in the form of documents / files and collecting data, legislaton , books, research journals and so on, through a literature research method of legislation related to micro-enterprise is carried out [35-40]. Related to this matter the author in conducting research studied several references relating to the increased marketing of salted egg micro enterprise in Pringsewu

2. Observation Method. Observation method is a research method wherein, the researcher observes / looks at and researches directly to the object of research about all activities related to the purpose of the research [4145], by analyzing the ongoing system and providing solutions through the information system to be build [46-49], so that it can be more useful [50-54]. Regarding the observation method, the author made a direct observation of the micro salted egg business to obtain some of the information needed related to the marketing carried out

3. Interview Method. The interview is a conversation between researcher and informant [55-60]. The researcher hopes to get information [61-65], while the informant is someone who is assumed having important information about an object [66-70]. In this case the author conducted interviews with micro business owners in order to obtain complete data information as well as the potential possessed. 
$\mathrm{R} 32=4 / \operatorname{Max}(6,4)=4 / 6=0.7$

\section{B. Research Flow Diagram}

Secondary data obtained from internal and external data [71-76] from employers, the results of previous research , and various literature related to this research.

\section{IMPLEMENTATION}

\section{A. Calculation Implementation}

Table 1. Salted egg criteria

\begin{tabular}{|l|l|}
\hline C1 & Taste of salted egg \\
\hline C2 & Shape of salted egg \\
\hline C3 & Colour of salted egg \\
\hline
\end{tabular}

Qualified salted egg calculation

Table 2. Taste of salted egg

\begin{tabular}{|l|l|l|}
\hline No & Taste of salted egg & Score \\
\hline 1 & Salty & 6 \\
\hline 2 & Rather salty & 4 \\
\hline
\end{tabular}

Table 3. Shape of salted egg

\begin{tabular}{|l|l|c|}
\hline No. & Shape of salted egg & Score \\
\hline 1 & Round & 5 \\
\hline 2 & Oval & 5 \\
\hline
\end{tabular}

Table 4. Colour of salted egg

\begin{tabular}{|l|l|l|}
\hline No. & Colour of salted egg & Score \\
\hline 1 & Dark blue & 6 \\
\hline 2 & Light blue & 4 \\
\hline
\end{tabular}

\section{Criteria}

There were two alternatives taken from Ambarawa subdistrict

$\mathrm{A}_{1}=$ salty

$\mathrm{A}_{2}=$ rather salty

As for the results from sample selection proposed can be seen on table below :

Table 5. Normalization

\begin{tabular}{|l|l|l|l|l|}
\hline No. & Name & C1 & C2 & C3 \\
\hline 1 & A1 & 6 & 5 & 6 \\
\hline 2 & A2 & 4 & 5 & 4 \\
\hline
\end{tabular}

On table 5 can be made normalization of $\mathrm{Ci}$

Salted egg taste:

$$
\mathrm{R} 11=6 / \operatorname{Max}(6,4)=6 / 6=1
$$$$
\mathrm{R} 12=4 / \operatorname{Max}(6,4)=4 / 6=0.7
$$

Shape egg taste

$\mathrm{R} 21=5 / \operatorname{Max}(5,5)=5 / 5=1$

$\mathrm{R} 22=5 / \operatorname{Max}(5,5)=5 / 5=1$

Color egg taste

$\mathrm{R} 31=6 / \operatorname{Max}(6,4)=6 / 6=1$

$$
\begin{aligned}
& \mathrm{A} 1=(6) *(1)+(5)^{*}(1)+(6) *(1) \\
& =6+5+6 \\
& =17 \\
& \mathrm{~A} 2=(4) *(0,7)+(5) *(1)+(4) *(0,7) \\
& =2,8+5+2,8 \\
& =10,6
\end{aligned}
$$

Greatest score of A1 to A1 (salted egg) was selected alternative as best alternative as qualified salted egg.

\section{B. Program Implementation}

Score weighting form functioned to peform weighting to all criteria. The following is display from weighting form score. Figure 1 shows salty score form and Figure 2 shows rather salty score form.

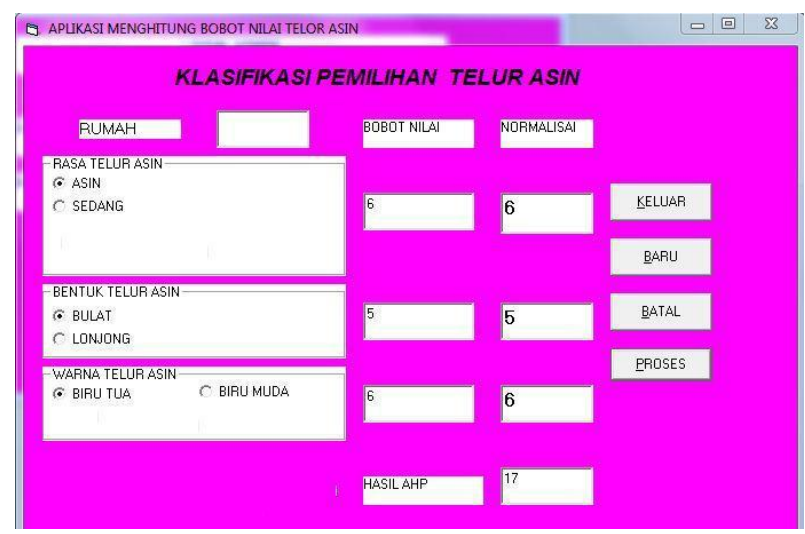

Figure 1. Salty Score Form

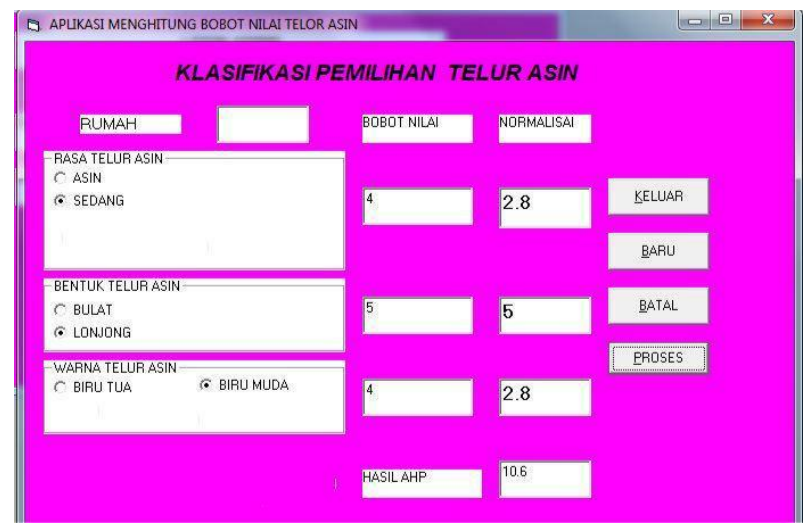

Figure 2. Rather salty score form

\section{V.CONCLUSION}

Weighting result of Salted Egg Micro Enterprise in Pringsewu Area based on alternative A1 Priority with weight 17 , alternative 2 with weight 10.6 . Based on the results of this study, to increase sales of Egg-Salted Micro Enterprise product, entrepreneurs can still maintain the Marketing mix that has been implemented so far. Thus, it is expected that the enterprise can continue to

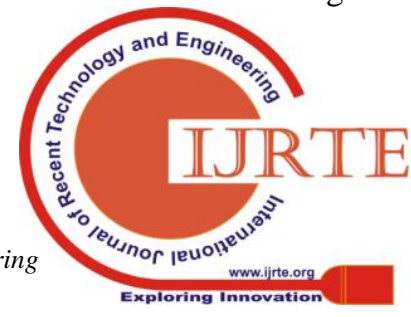


make the best use of the five Marketing mixes so that the increase in salted egg Micro enterprise will be maintained because applying the five Marketing mixes is a perfect way to cover the entire approach that has been done through the media to the personal. It is needed a further research on the marketing strategies in other salted egg micro enterprise areas so that the priority marketing objectives 2 . Program Implementation were maintaining and increasing the Salted Egg Micro Enterprise market share that can be achieved nationally, as well as research related to consumer behavior to see the impact of strategy application of Micro Enterprsie Marketing of Salted Eggs.

\section{REFERENCES}

[1]. Sychugov, A. A., Akhmetshin, E. M., Grishin, V. M., Shpakova, R. N., \& Plotnikov, A. V. (2019). Algorithm determine trust value to the distributed information systems elements. Journal of Mechanical Engineering Research and Developments, 42(2), 6-9. doi:10.26480/jmerd.02.2019.06.09

[2]. Shi, X., Sarafbidabad, M., Ibatova, A. Z., Razavi, R., \& Najafi, M. (2019). Potential of doped nanocones as catalysts for $\mathrm{N} 2 \mathrm{O}+\mathrm{CO}$ reaction: Theoretical investigation. Journal of Cluster Science, 30(1), 61-67. doi:10.1007/s10876-018-1463-6

[3]. Natalie P. Nikonova, Larisa N. Gorina, Andino Maseleno, Inter-Regional Relationship Based on Geo Economics Requirements, International Journal of Recent Technology and Engineering (IJRTE), Vol. 7, Issue 6S5, pp. 204-206, 2019.

[4]. Fenny Syafariani R., Andri Sahata Sitanggang, Eko Yudhi Pramono, Wahidah Hashim, Andino Maseleno, Systems and Services Pattern Descriptions at Daycare, International Journal of Recent Technology and Engineering (IJRTE), Vol. 7, Issue 6S5, pp. 207-212, 2019.

[5]. Tri Susilowati, P. Manickam, G. Devika, K. Shankar, Latifah, Muhamad Muslihudin, Wahidah Hashim, Miftachul Huda, Aleksandr Aleeksevich Korostelev, Andino Maseleno, Decision Support System for Determining Lecturer Scholarships for Doctoral Study Using CBR (Case-Based Reasoning) Method, International Journal of Recent Technology and Engineering (IJRTE), 2019. pp. 3281-3290.

[6]. Muhamad Muslihudin, M. Ilayaraja, K. Sathesh Kumar, K. Shankar, Jauharotun Jamilah, Dita Novitasari, Miftachul Huda, Wahidah Hashim, Irina V. Rudenko, Andino Selection using TOPSIS Method, International Journal of Recent Technology and Engineering (IJRTE), 2019. pp.3291-3298.

[7]. Muhamad Muslihudin, G. Devika, P. Manickam, K. Shankar, Dian Permana Putra, Eki Pramudia Sukarno Putra, Miftachul Huda, Wahidah Hashim, Oksana P. Denisova, Andino Maseleno, Expert System in Determining Baby Disease using Web Mobile-based Weighted Product Method, International Journal of Recent Technology and Engineering (IJRTE), 2019. pp.3299-3308.

[8]. Muhamad Muslihudin, K. Sathesh Kumar, M. Ilayaraja, K Shankar, Lailaturrohmah, Dian Permana Putra, Wahidah Hashim, Andino Maseleno, Expert System in Determining the Quality of Nutmeg Breed using Website-Based Forward Chaining Methods, International Journal of Recent Technology and Engineering (IJRTE), 2019. pp.3309-3318.

[9]. Muhamad Muslihudin, S. Hemalatha, K. Shankar, Eswaran Perumal, Nofiyanti, Satria Abadi, Wahidah Hashim, Andino Maseleno, Application of Expert System for Determining Export Quality Pepper Seeds using Website-Based Forward Chaining Method, International Journal of Recent Technology and Engineering (IJRTE), 2019. pp. 3319-3329.

[10]. Muhamad Muslihudin, Rizky Purnama, Wahidah Hashim, Andino Maseleno, Selection of Temporary Landfill using Fuzzy Multiple Attribute, International Journal of Innovative Technology and Exploring Engineering, 2019. pp.598-604.

[11]. Muhamad Muslihudin, Siti Mukodimah, Erma Dwiyani, Maseleno, Decision Support System in Kindergarten

Trisnawati, Wahidah Hashim, Andino Maseleno, Fuzzy Logic Prediction of Dengue Hemorrhagic Fever Distribution in Pringsewu Region, International Journal of Innovative Technology and Exploring Engineering, 2019. pp.605-612.

[12]. S. Senthil, B. Ayshwarya, Prediction of Lung Cancer using Blue Whale Optimizer Algorithm with Neural Network Classifier, Journal of Advanced Research in Dynamical and Control Systems, Volume 11, 02-Special Issue, 2019. pp. 1737-1748.

[13]. Narges Bahrami, Sifeng Liu, Vadim Vitalievich Ponkratov, Phong Thanh Nguyen, Andino Maseleno, Stephen Berti, Novel Load Management for Renewable Generation Sources/Battery System through Cut Energy Expenditure and Generate Revenue, International Journal of Ambient Energy, Taylor and Francis Online, 2019.

[14]. Aravindhan Surendar, J. Muralidharan, Ali Dehghan Saee, Andino Maseleno, Aleksandr Alekseevich Rudenko, David Ros, Mathematical modelling of free convection in an ellipse-rectangular annulus filled with nanofluid using LBM, Thermal Science and Engineering Progress, Elsevier, 2019

[15]. Elena V. Smirnova, B. Ayshwarya, Phong Thanh Nguyen, Wahidah Hashim, Andino Maseleno, Using Shell Programs in Educational and Methodological Support for Learning Foreign Language, International Journal of Applied Exercise Physiology, Vol. 8 (2.1), 2019. pp. 1027-1032.

[16]. Inga E. Rakhimbaeva, Aleksandr A. Korostelev, Indira A. Shakirova, B. Ayshwarya, Phong Thanh Nguyen, Wahidah Hashim, Andino Maseleno, Integration of the Educational and Didactic Systems in the Training of Future Teachers, International Journal of Applied Exercise Physiology, Vol. 8 (2.1), 2019. pp. 1033-1038.

[17]. Alla L. Busygina, Elena M. Chertakova, Darya B. Shtrikova, B. Ayshwarya, Phong Thanh Nguyen, Wahidah Hashim, Andino Maseleno, Professional forms of Employment in the Russian Federation: Problems and Challenges, International Journal of Applied Exercise Physiology, Vol. 8 (2.1), 2019. pp. 1039-1045.

[18]. Olga I. Pugach, Andrei V. Ochepovsky, Wahidah Hashim, Andino Maseleno, B.Ayshwarya, Phong Thanh Nguyen, To the use of English Words When Learning Programming, Information Systems and Technologies, International Journal of Applied Exercise Physiology, Vol. 8 (2.1), 2019. pp. 1046-1051.

[19]. Satria Abadi, Akmal Hawi, Akla, Ihsan Dacholfany, Miftachul Huda, Kamarul Shukri Mat Teh, Jaki Walidi, Wahidah Hashim, Andino Maseleno, Identification of Sundep, Leahopper and Fungus of Paddy by using Fuzzy SAW Method, International Journal of Pharmaceutical Research, Volume 11, Issue 1, January - March 2019.

[20]. Andino Maseleno, Miftachul Huda, Kamarul Azmi Jasmi,Bushrah Basiron, Ismail Mustari, Abdul Ghaffar Don, Roslee bin Ahmad, Hau-Kashyap Approach for Student's Level of Expertise, Egyptian Informatics Journal, Elsevier, Vol. 20, Issue 1, March 2019, pp. 27-32.

[21]. Liang Zhou, Hesam Kamyab, Aravindhan Surendar, Andino Maseleno, Aygul Z. Ibatova, Shreeshivadasan Chelliapan, Nima Karachi, Zohreh Parsaee, Novel Z-scheme composite Ag2CrO4/NG/polyimides as high performance nano catalyst for photoreduction of $\mathrm{CO} 2$ : Design, fabrication, characterization and mechanism, Journal of Photochemistry and Photobiology A: Chemistry, Elsevier, Volume 368, 1 January 2019, pp 30-40.

[22]. Muhamad Rusliyadi, Azaharaini bin Hj. Mohd. Jamil, Marini Othman, Andino Maseleno, Ratna Tri Kumalasari, Agricultural Extension Policy, Agricultural Growth and Poverty Reduction in Indonesia, International Journal of Engineering and Technology (UAE), Vol. 7, No. 4, 2018, pp. 5539-5550.

[23]. Gunawan Budiyanto, Sri Ipnuwati, Sayyid Azam Al Gifari, Miftachul Huda, Burhanuddin Jalal, Aliza Abdul Latif, Andino Maseleno, April Lia Hananto, Web based expert system for diagnosing disease pest on banana plant, International Journal of Engineering and Technology(UAE), Vol. 7, No. 4, 2018, pp. 4715-4721. 
[24]. Elisabet Yunaeti Anggraeni, Pardimin, Ihsan Dacholfany, Akla, Miftachul Huda, Kamarul Shukri Mat Teh, Aminudin Hehsan, Juhazren Junaidi, Farahwahida Mohd Yusof, Hafiza Abas, Mohd Fauzi Abu Husin, Dina Apriani, Aliza Abdul Latif, Andino Maseleno, Modelling effectivenes of IS learning methodology with AHP method, International Journal of Engineering and Technology(UAE), Vol. 7, No. 4, 2018, pp. 4708-4714.

[25]. Aditya Mulawarman, Ajat Sudrajat, Nedi Hendri, Karnawi Kamar, Dedi Mulyadi, Gunawan Budiyanto, Miftachul Huda, Aliza Abdul Latif, Andino Maseleno, FMADM for determining superior commodity at agroindustry area, International Journal of Engineering and Technology(UAE), Vol. 7, No. 4, 2018, pp. 4667-4673.

[26]. Dwi Kurniasih Kamarul Azmi Jasmi, Bushrah Basiron, Miftachul Huda, Andino Maseleno, The uses of fuzzy logic method for finding agriculture and livestock value of potential village, International Journal of Engineering and Technology(UAE), Vol. 7, No. 3, 2018, pp. 1091-1095.

[27]. Hana Adela, Kamarul Azmi Jasmi, Bushrah Basiron, Miftachul Huda, Andino Maseleno, Selection of Dancer Member using Simple Additive Weighting, International Journal of Engineering and Technology(UAE), Vol. 7, No. 3, 2018, pp. 1096-1107.

[28]. Tri Susilowati, M. Ihsan Dacholfany, Sudirman Aminin, Afiful Ikhwan, Badlihisham Mohd. Nasir, Miftachul Huda, Adi Prasetyo, Andino Maseleno, Fiqih Satria, Sri Hartati, Wulandari, Getting Parents Involved in Child's School Using Attendance Application System based on SMS Gateway, International Journal of Engineering and Technology(UAE), Vol. 7, No. 2.27, 2018, pp. 167-174.

[29]. Andino Maseleno, Alicia Y.C. Tang, Moamin A. Mahmoud, Marini Othman, Suhendi Saputra, Muhamad Muslihudin, Fuzzy AHP Method to Determine Headache Types based on Symptoms, Investigacion Clinica, Vol. 58, No. 1, 2017.

[30]. Aprianti Putri Sujana, Andri Sahata Sitanggang, Andino Maseleno, Application of E-Transport through Android-Based Ticketing Applications, Journal of Advanced Research in Dynamical and Control Systems, Issue 13-Special Issue, 2018, pp. 1347-1356.

[31]. Pardimin, Apriadi, Widhiya Ninsiana, M. Ihsan Dacholfany, Karnawi Kamar, Kamarul Shukri Mat Teh, Miftachul Huda, April Lia Hananto, Muhammad Muslihudin, K. Shankar, Natalia V. Kamenez, Andino Maseleno, Developing Multimedia Application Model for Basic Mathematics Learning, Journal of Advanced Research in Dynamical and Control Systems, Issue 14-Special Issue, 2018, pp. 1347-1356.

[32]. Natalia V. Kamenez, Olga Igorevna Vaganova, Zhanna Venediktovna Smirnova, Marina Nikolaevan Bulayeva, Ekaterina Andreevna Kuznetsova, Andino Maseleno, Experience of the use of electronic training in the educational process of the Russian higher educational institution, International Journal of Engineering and Technology(UAE), Vol. 7, No. 4, pp. 4085-4089, 2018.

[33]. Olga Igorevna Vaganova, Ludmila N. Zanfir, Zhanna Venediktovna Smirnova, Elena Aleksandrovna Chelnokova, Svetlana Nikolaevna Kaznacheeva, Andino Maseleno, On the linguistic training of future teachers of unlike specialties under the conditions of Russian professional education, International Journal of Engineering and Technology(UAE), Vol. 7, No. 4, pp. 4090-4095, 2018.

[34]. Olga Igorevna Vaganova, Natalia V. Kamenez, Vinnikova Irinia Sergeevna, Ekaterina Vladimirovna Vovk, Zhanna Venediktovna Smirnova, Andino Maseleno, Possibilities of information technologies to increase quality of educational services in Russia, International Journal of Engineering and Technology(UAE), Vol. 7, No. 4, pp. 4096-4102, 2018.

[35]. Zhanna Venediktovna Smirnova, Ludmila N. Zanfir, Olga Igorevna Vaganova, Natalia Vasilevna Bystrova, Nina Vladimirovna Frolova, Andino Maseleno, WorldSkills as means of improving quality of pedagogical staff training, International Journal of Engineering and Technology(UAE), Vol. 7, No. 4, pp. 4103-4108, 2018.

[36]. Abdul Hamid, Ajat Sudrajat, Razaleigh Muhamat Kawangit,
Abdul Ghafar Don, Miftachul Huda, Burhanuddin Jalal, Wahyu Akbar, Azura Onn, Andino Maseleno, Determining basic food quality using SAW, International Journal of Engineering and Technology(UAE), Vol. 7, No. 4, pp. 3548-3555, 2018.

[37]. Noca Yolanda Sari, Miftachul Huda, Kamarul Shukri Mat Teh, Anggia Sari, Ramona Ramli, Andino Maseleno, Decision support system for determining chili plant using fuzzy multiple attribute decision making, International Journal of Engineering and Technology(UAE), Vol. 7, No. 4, pp. 3556-3562, 2018.

[38]. Oktafianto, Ajat Sudrajat Kawangit, Razaleigh Muhamat Kawangit, Abdul Ghafar Don, Miftachul Huda, Amel Dhea Saputri,Aliza Abdul Latif, Andino Maseleno, Determining housing location using weighted product, International Journal of Engineering and Technology(UAE), Vol. 7, No. 4, pp. 3563-3568, 2018.

[39]. Satria Abadi, Miftachul Huda, Kamarul Shukri Mat Teh, Zulkiflee Haron, Mohd. Nasir Ripin, Aminudin Hehsan, Shamsul Sarip, Muhamad Rafiqi Hehsan, Musfika Amrullah, Andino Maseleno, Hazard Level of Vehicle Smoke by Fuzzy Multiple Attribute Decision Making with Simple Additive Weighting Method, International Journal of Pharmaceutical Research, Vol. 10, Issue 4, 2018.

[40]. Fauzi, Miftachul Huda, Kamarul Shukri Mat Teh, Zulkiflee Haron, Mohd. Nasir Ripin, Aminudin Hehsan, Hafiza Abas, Muhamad Rafiq, July Irawan, Satria Abadi, Andino Maseleno, The Design of Fuzzy Expert System Implementation for Analyzing Transmissible Disease of Human, International Journal of Pharmaceutical Research, Vol. 10, Issue 4, 2018.

[41]. Mohamed Elhoseny, K. Shankar, S.K. Lakshmanaprabu, Andino Maseleno, N. Arunkumar, Hybrid Optimization with Cryptography Encryption for Medical Image Security in Internet of Things, Neural Computing and Applications, Springer, October 2018, pp. 1-15.

[42]. E. Laxmi Lydia, P. Krishna Kumar, K. Shankar, S.K. Lakshmanaprabu, R.M. Vidhyavathi, Andino Maseleno, Charismatic Document Clustering through Novel K-Means Non-negative Matrix Factorization (KNMF) Algorithm using Key Phrase Extraction, International Journal of Parallel Programming, Springer, 2018, pp. 1-19.

[43]. K. Shankar, S.K. Lakshmanaprabu, Deepak Gupta, Andino Maseleno, Victor Hugo C. De Albuquerque, Optimal feature-basedmulti-kernel SVM approach for thyroid disease classification, The Journal of Supercomputing, Springer, Vol. 74, no. 259, 2018, pp. 1-16.

[44]. M. Miftakul Amin, Adi Sutrisman, Deris Stiawan, Andino Maseleno, Design Restful WebService of National Population Database for supporting E-health interoperability service, Journal of Theoretical and Applied Information Technology, vol. 96, issue 15, 2018.

[45]. A.H. Motlagh, S.V. Klyuev, Aravindhan Surendar, Aygul Z. Ibatova, Andino Maseleno, Catalytic Gasification of Oil Sludge with Calcined Dolomite, Petroleum Science and Technology, Taylor and Francis, pp. 1-5, 2018.

[46]. Aravindhan Surendar, Alireza Bozorgian, Andino Maseleno, Lubov K. Ilyashenko, Meysam Najafi, Oxidation of Toxic Gases via Ge-B36N36 and Ge-C72 Nanocages as Potential Calaysts, Inorganic Chemistry Communications, Elsevier, Vol. 96, October 2018, pp. 206-210.

[47]. Abdolhamid Namdarian, Amin Goljanian Tabrizi, Andino Maseleno, Abdolkhaled Mohammadi, Seyyed Ebrahim Mossavifard, One step synthesis of rGO-Ni3S2 nano-cubes composite for high-performance supercapacitor electrodes, International Journal of Hydrogen Energy, Elsevier, vol. 43, Issue 37, 13 September 2018, pp.17780-17787.

[48]. Aravindhan Surendar, Lina G. Akhmetov, Lubov K. Ilyashenko, Andino Maseleno, Vahid Samavatian, Effect of thermal cycle loadings on mechanical properties and thermal conductivity of a porous lead-free solder joint, IEEE Transactions on Components, Packaging, and Manufacturing Technology, 2018, pp. 1769-1776.

[49]. Aravindhan Surendar, Vahid Samavatian, Andino Maseleno, Aygul Z. Ibatova,

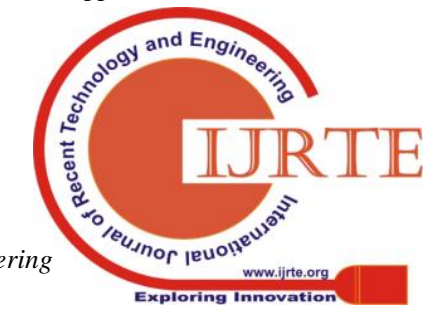


Samavatian, Effect of solder layer thickness of thermo-mechanical reliability of a power electronic system, Journal of Material Science: Materials in Electronics, Springer, September 2018, Volume 29, Issue 17, pp. 15249-15258.

[50]. Majid Samavatian, Lubov K. Ilyashenko, Aravindhan Surendar, Andino Maseleno, Vahid Samavatian, Effect of System Design on Fatigue Life of Solder Joints in BGA Packages Under Vibration at Random Frequencies, Journal of Electronic Materials, November 2018, Volume 47, Issue 11, pp. 6781-6790.

[51]. Ilgar Javanshir, Andino Maseleno, Shahin Tasoujian, Majid Oveisi, Optimization of suspension system of heavy off-road vehicle for stability enhancement using integrated anti-roll bar and coiling spring mechanism, Journal of Central South University, September 2018, Volume 25, Issue 9, pp 2289-2298.

[52]. Andino Maseleno, Alicia Y.C. Tang, Moamin A. Mahmoud, Marini Othman, K. Shankar, Big Data and E-Learning in Education, International Journal of Computer Science and Network Security, 2018, Vol. 18, No. 5, pp. $171-174$

[53]. Muhammad Assahubulkahfi, Yahaya Md. Sam, Andino Maseleno, Miftachul Huda, LQR Tuning by Particle Swarm Optimization of Full Car Suspension System, International Journal of Engineering and Technology(UAE), Vol. 7, No. 2.13, 2018, pp. 328-331.

[54]. Andino Maseleno, Miftachul Huda, Maragustam Siregar, Roslee Ahmad, Aminudin Hehsan, Zulkiflee Haroon, Moh Nasir Ripin, Siti Suhaila Ikhwani, Kamarul Azmi Jasmi, Combining the Previous Measure of Evidence to Educational Entrance Examination, Journal of Artificial Intelligence, Vol. 10, No. 3, pp. 85-90, 2017. ISSN: 2077-2173. doi: 3923/jai.2017.85.90

[55]. Miftachul Huda, Andino Maseleno, Kamarul Azmi Jasmi, Ismail Mustari, Bushrah Basiron, Strengthening Interaction from Direct to Virtual Basis: Insights from Ethical and Professional Empowerment, International Journal of Applied Engineering Research, Vol. 12, No. 17, pp. 6901-6909, 2017. ISSN: 0973-4562.

[56]. Miftachul Huda, Andino Maseleno, Masitah Shahrill, Kamarul Azmi Jasmi, Ismail Mustari, Bushrah Basiron, Exploring Adaptive Teaching Competencies in Big Data Era, International Journal of Emerging Technologies in Learning, Vol. 12, No. 3, pp. 68-83, 2017. ISSN: 1863-0383. doi: 10.3991/ijet.v12i03.6434.

[57]. Andino Maseleno, Glenn Hardaker, Noraisikin Sabani, Nabilah Suhaili, Data on multicultural education and diagnostic information profiling: Culture, learning styles and creativity, Data in Brief, Elsevier, Vol. 9, pp. 1048-1051, December 2016. doi: 10.1016/j.dib.2016.11.024.

[58]. Andino Maseleno, Md. Mahmud Hasan, Norjaidi Tuah, Charles Rangga Tabbu, Fuzzy Logic and Dempster-Shafer Theory to Predict The Risk of Highly Pathogenic Avian Influenza H5N1 Spreading, World Applied Science Journal, Vol. 34, No. 8, pp. 995-1003, 2016. ISSN: 1818-4952. doi: 10.5829/idosi.wasj.2016.34.8.15688

[59]. Andino Maseleno, Glenn Hardaker, Malaria Detection using Mathematical Theory of Evidence, Songklanakarin Journal of Science and Technology, Vol. 38, No. 3, pp. 257-263, 2016. ISSN: 0125-3395. doi:10.14456/sjst-psu.2016.35

[60]. Andino Maseleno, Md. Mahmud Hasan, Muhammad Muslihudin, Tri Susilowati, Finding Kicking Range of Sepak Takraw Game: Fuzzy Logic and Dempster-Shafer Theory Approach, Indonesian Journal of Electrical Engineering and Computer Science, Vol. 2, No. 1, pp. 187 - 193, 2016. ISSN: 2502-4752. doi: 10.11591/ijeecs.v2.i1.pp187-193

[61]. Andino Maseleno, Md. Mahmud Hasan, Norjaidi Tuah, Fauzi, Muhammad Muslihudin, Fuzzy Logic Combined with Dempster-Shafer Theory for African Trypanosomiasis Spreading Prediction, Middle-East Journal of Scientific Research, Vol. 23, No. 9, pp. 2307 - 2317, 2015 ISSN: 1990-9233, doi: 10.5829/idosi.mejsr.2015.23.09.22600

[62]. Andino Maseleno, Md. Mahmud Hasan, Norjaidi Tuah, Combining Fuzzy Logic and Dempster-Shafer Theory,
TELKOMNIKA, Vol. 16, No. 3, pp. 583-590, 2015. ISSN: 2302-404. doi: 10.11591/telkomnika.v16i3.9370

[63]. Bibi Rawiyah Mulung, Andino Maseleno, Proposed SMART Traffic Control Signal in Brunei Darussalam, TELKOMNIKA, Vol. 15, No. 2, pp. 277-282, 2015. ISSN: 2302-4046. doi: 10.11591/telkomnika.v15i2.8109

[64]. P. Uma Maheswari, P. Manickam, K. Sathesh Kumar, Andino Maseleno, K. Shankar, Bat optimization algorithm with fuzzy based PIT sharing (BF-PIT) algorithm for Named Data Networking (NDN), Journal of Intelligent \& Fuzzy Systems, IOS Press, pp. 1-8, 2019.

[65]. Grigory Olegovich Yarygin, Aleksandr Aleeksevich Korostelev, Rafis H. Mukhutdinov, Andino Maseleno, Elections and Russian Citizens Residing Overseas: Prospects for Internet Voting, International Journal of Recent Technology and Engineering (IJRTE), Vol. 7, Issue 6S5, pp. 52-57, 2019.

[66]. Larisa Akhunzhanovna Apanasyuk, Elena Vladimirovna Smirnova, Rafis H. Mukhutdinov, Andino Maseleno, The Problem of the Organization of Socio-Cultural Environment for Adaptation and Development of a Student-Migrant's Bilingual Identity in the Conditions of the Russian Higher Education, International Journal of Recent Technology and Engineering (IJRTE), Vol. 7, Issue 6S5, pp. 63-70, 2019.

[67]. Alla L. Busygina, Liliya A. Meteleva, Darya B. Shtrikova, Rafis H. Mukhutdinov, Andino Maseleno, Bases of Formation of Women's Professional Mentality in Russia, International Journal of Recent Technology and Engineering (IJRTE), Vol. 7, Issue 6S5, pp. 71-77, 2019.

[68]. Oleg N. Yarygin, Aleksandr A. Korostelev, Linar G. Akhmetov, Andino Maseleno, Modeling of Competence as a Tool of Goal Setting for Education in Modern Society, International Journal of Recent Technology and Engineering (IJRTE), Vol. 7, Issue 6S5, pp. 78-86, 2019.

[69]. Raven John, Aleksandr A. Korostelev, Oleg N. Yarygin, Rafis H. Mukhutdinov, Andino Maseleno, The Genesys and Base Concepts of Competentology, International Journal of Recent Technology and Engineering (IJRTE), Vol. 7, Issue 6S5, pp. 87-95, 2019.

[70]. Bogdanova Anna Vladimirovna, Aleksandr Alekseevich Korostelev, Rafis H. Mukhutdinov, Indira A. Shakirova, Andino Maseleno, Formulation of the Problem of Mathematical Modeling of Accommodation of Basic Stations of Cellular Communication in Residential Territories for Students of It-Directions of Preparation, International Journal of Recent Technology and Engineering (IJRTE), Vol. 7, Issue 6S5, pp. 96-100, 2019.

[71]. Bogdanova A. Vladimirovna, Aleksandr A. Korostelev, Olga L. Shepelyuk, Anna E. Rodionova, Irina N. Fardeeva, Andino Maseleno, Reengineering of Business Processes of the Higher School: Its Prerequisites, International Journal of Recent Technology and Engineering (IJRTE), Vol. 7, Issue 6S5, pp. 101-104, 2019.

[72]. Rustem R. Vakhitov, Anna E. Rodionova, Elena V. Smirnova, Rafis H. Mukhutdinov, Mariya I. Arzhakova, Andino Maseleno, Crisis of Higher Education in Russia, International Journal of Recent Technology and Engineering (IJRTE), Vol. 7, Issue 6S5, pp. 105-109, 2019.

[73]. Kuznetsov Sergey Vladimirovich, Magizov Rustem Robertovich, Radzevanovskaya Yuliya Viktorovna, Alexey V. Kuznetsov, Mukhametgaliev Iskandar Gabdulvaliyevich, Andino Maseleno, Public Anti-Corruption Control as a Mechanism to Counter Corruption in the Russian Federation, International Journal of Recent Technology and Engineering (IJRTE), Vol. 7, Issue 6S5, pp. 110-113, 2019.

[74]. R. Fenny Syafariani, Andri Sahata Sitanggang, Andino Maseleno, Application of Backend and Frontend Systems on Go-Baby Application in Bandung City, International Journal of Recent Technology and Engineering (IJRTE), Vol. 7, Issue 6S5, pp. 125-131, 2019.

[75]. Natalia L. Ivanova, Nikolay Ivanovich Sinyavsky, Alexey Valerievich Fursov,

Oksana Petrovna

Denisova, Andino

Maseleno, Future Oil and Gas Students' Attitude to 
Healthy Lifestyle and Their Participation in the Implementation of Russian Physical Educational Complex «Ready for Labor and Defense» (Rld) Normatives, International Journal of Recent Technology and Engineering (IJRTE), Vol. 7, Issue 6S5, pp. 186-189, 2019.

[76]. Natalia P. Nikonova, Larisa N. Gorina, Andino Maseleno, Cooperation between the European Union and the Eurasian Union, International Journal of Recent Technology and Engineering (IJRTE), Vol. 7, Issue 6S5, pp. 201-203, 2019. 